\title{
Reproductive systems biology tackles global issues of population growth, food safety and reproductive health
}

\author{
Peter Sutovsky ${ }^{1,2} \cdot$ Andrea S. Cupp $^{3} \cdot$ Winston Thompson ${ }^{4,5} \cdot$ Mark Baker $^{6}$
}

Published online: 17 November 2015

(C) Springer-Verlag Berlin Heidelberg 2015

\section{Introduction}

With a steadily increasing world population, humanity faces formidable challenges in securing commensurate food sources and increasing well being and life expectancy worldwide while at the same time mitigating environmental impacts and assuring reproductive rights to all. Reproductive biology generates important new knowledge necessary for more efficient food animal production, human reproductive health, voluntary, user-controlled birth/population control, prevention and management of sexually-transmitted diseases and sciencebased policymaking aimed at safeguarding and promoting new assisted reproductive therapies. Based on different fertility scenarios, the world population is projected to reach between 9.6 and 25 billion by the year 2050 (Jensen 2011). At the same time, HIV and other sexually-transmitted diseases (STD) remain a major concern with millions of new cases

Peter Sutovsky

SutovskyP@missouri.edu

1 Division of Animal Sciences, University of Missouri, S141 ASRC, 920 East Campus Drive, Columbia, MO 65211-5300, USA

2 Department of Obstetrics, Gynecology \& Women's Health, University of Missouri, S141 ASRC, 920 East Campus Drive, Columbia, MO 65211-5300, USA

3 Department of Animal Science, University of Nebraska-Lincoln, 3940 Fair Street, Lincoln, NE 68583-0908, USA

4 Department of Obstetrics and Gynecology, Morehouse School of Medicine, Atlanta, GA 30310, USA

5 Department of Physiology, Morehouse School of Medicine, Atlanta, GA 30310, USA

6 Reproductive Proteomics, Discipline of Biological, Sciences, University of Newcastle, Callaghan, NSW 2308, Australia appearing every year, and the use of contraceptive technologies varies greatly between countries, regions and demographic categories (Friend and Doncel 2010). The present second special issue of Cell andTissue Research on reproduction offers a window into state-of-the-art cell biological/molecular approaches to study human and animal reproductive systems. Besides clinical research and research on rodent animals, studies employing large livestock animal models are reviewed prominently as the improvement of reproductive efficiency in food animals is increasingly predicted to drive world food supply.

\section{Animal reproductive biology for sustainable agriculture and biomedical model development}

A fast-growing population, industrialization and accelerated economic growth spur the growth of an affluent middle class, which increases the demand for meat and other animal source foods in rapidly developing countries such as China (Wu et al. 2014). Meat and dairy production depends greatly on increased efficiency of artificial insemination, in vitro embryo culture and commercial embryo transfer. Industrial-scale farming relies heavily on germplasm of male animals with superior genetic traits, for which testicular output and sperm quality are of the highest importance. Focusing on testicular development and function, the article by Sargent et al. proposes that differential splicing of the gene encoding vascular endothelial growth factor A (VEGFA) into angiogenic and antiangiogenic isoforms is a contributing factor to the balance of spermatogonial stem cell self-renewal and differentiation (Sargent et al. 2015). Novelty lies in the fact that VEGFA has an avascular role, identified through conditional knockout mice with elimination of VEGFA in somatic cells, independent of its previously-identified function in both male and 
female sex-specific vascular development during gonadal differentiation (Bott et al. 2010).

Semen cryopreservation and artificial insemination remain inefficient in the swine industry, and a continuous challenge in other species, partly due to a lack of understanding of structural changes occurring in the sperm head as a prelude to fertilization (Tsai et al. 2010). Towards this goal, van Gestel et al. (2015) shed light on sperm function and particularly on the composition of lipid membrane rafts that are important during the process of sperm capacitation, and that release spermatozoa from a reservoir within the female reproductive tract and endow them with the capacity to fertilize. Complementing the above article, a review by J. E. Flechon provides both the historic perspective and some provocative new ideas about sperm acrosomal structure and function (Flechon 2015), which has been reinterpreted recently in view of studies suggesting that acrosomal exocytosis, at least in the mouse, starts even before the spermatozoa contact the egg coat (Jin et al. 2011). Continuing with the theme of sperm priming for fertilization, Plante et al. revisit the structure, properties, function and evolution of mammalian seminal plasma-derived binder of sperm proteins (BSP; Manjunath et al. 2009) involved in sperm interactions with female oviductal epithelia, and explore their interactions with cryoprotectants and components of semen extender used for semen cryopreservation (Plante et al. 2015). Some of the first BSP studies came from the laboratory of S. Suarez (Ignotz et al. 2001), who contributed a detailed review of sperm transport in the female reproductive tract (Suarez 2015), a body of knowledge important for development of timed artificial insemination in animals, as well as for infertility diagnostics and treatment in humans.

Moving on from sperm transport towards gamete interactions, one of the most exciting recent developments in fertilization biology is the identification of the elusive sperm receptor molecule on the mammalian oocyte plasma membrane. Consequently, innovative approaches to membrane receptor identification and characterization of gametic surface protein interactions are reviewed by Wright and Bianchi (2015), the discoverers of the mammalian sperm receptor protein JUNO (Bianchi et al. 2014). Subsequent to the JUNO-mediated gamete fusion, sperm-borne cytosolic factors are released to trigger an oocyte activation process that encompasses the completion of oocyte meiosis, the activation of defense mechanisms preventing pathological polyspermic fertilization, and the formation of maternal and paternal pronuclei. The central role of sustained post-fertilization calcium signaling (Wang et al. 2015) in these early developmental events is reviewed by Z. Machaty with particular focus on large animal models (Machaty 2015).

As much as $50 \%$ of human embryos are estimated to be lost before implantation. Similarly, livestock embryos conceived by artificial insemination (AI) or produced in vitro and transferred to recipients are prone to early embryonic death resulting in early pregnancy losses that lower AI conception rates down to $35-45 \%$ and account for millions of lost dollars in the beef and dairy cattle industries (Hansen et al. 2004). In this regard, P. Hansen et al. discuss the sex-specific expression of colony stimulating factor CSF2 (Loureiro et al. 2009) and related mechanisms guiding preimplantation embryo programming, which leads to the establishment and sustenance of pregnancy, a developmental milestone that is equally important for the management of human and animal reproductive health (Hansen et al. 2015). Among possible causes of preimplantation embryo changes that may lead to developmental arrest and epigenetic abnormalities, the endoplasmatic reticulum stress (Hao et al. 2009), caused by exogenous factors during laboratory procedures necessary for human/animal embryo production, is discussed by Latham (2015). Also concerned with early development, a review by Ortega et al. centers on the zygote, the earliest stage of embryonic development, during which pronuclear formation sets the stage for zygotic genome activation and epigenetic reprograming which promotes successful embryo development in animals or humans (Ortega et al. 2015). In particular, the authors examine the role of origin of recognition complex (ORC) proteins (Ortega et al. 2012) in zygotic DNA replication and examine their function during chromosome segregation and asymmetric division during oocyte meiosis.

While genetic engineering holds unprecedented potential for improvement of livestock production and reproductive traits with great potential for producing cheaper nutrient-rich animal protein, the current negative public perception makes it almost entirely likely that genetically modified meat and milk will not enter the human food chain anytime soon. This perception could be changed by food animals created with new gene editing technologies such as TALENs and CRISPRs (Whitworth et al. 2014) as discussed by K. Wells, who also emphasizes the utility of genetically-modified large animal models for biomedical research (Wells 2015).

\section{Human reproductive health and population growth}

In a career-oriented society, the increasing age of first-time parents drives the need for improving and safeguarding assisted reproductive therapies (ART). Better understanding of placental and ovarian function enables the discovery of new cellular pathways, arming obstetricians with better diagnostic and therapeutic tools, and giving older first-time mothers a better chance of conceiving and bearing healthy children. Equally critical for the success of natural and assisted conception is proper ovarian function. Among the exciting new directions in the study of ovary, the involvement of small regulatory RNAs, such as microRNAs (McGinnis et al. 2015) in the regulation of follicular recruitment, atresia and luteinization, and their clinical relevance is discussed by Maalouf 
et al. (2015). Focusing on the ovarian somatic compartment rather than oocyte itself, Chowdhury et al. discuss the role of mitochondrial membrane protein prohibitin (Chowdhury et al. 2007) in ovarian granulosa cell survival, differentiation and function at the crossroads of ovarian steroidogenesis and mitochondrial function (Chowdhury et al. 2015).

The age-related decline in oocyte quality is established during oogenesis and oocyte maturation, which has a bearing on the incidence of chromosomal defects implicated in agerelated female infertility (Hassold and Hunt 2009). In this context, an overview of oocyte maturation, with particular focus on maternal mRNA recruitment and protein synthesis, processing and stabilization is given by Susor et al. (2015), while X.J. Liu explains the cell biological approaches to the study of maternal-age related oocyte aneuploidy (Liu 2015). Together, such studies of oocyte maturation help us understand female reproductive aging and may identify noninvasive markers of oocyte quality predictive of developmental potential after assisted fertilization. Picking up where the latter paper leaves off, B. Daughtry and S. Chavez offer a thorough analysis of chromosomal abnormalities in preimplantation embryos (Daughtry and Chavez 2015), and discuss recent technological achievements in genetic, epigenetic, chromosomal and non-invasive embryo assessment (Chavez et al. 2012). Preimplantation development sets the stage for the establishment of pregnancy. The immunologically foreign embryo at this stage and the fetus later on is an allograft protected from an attack by maternal immune system by intricate immunodefensive mechanisms that are not yet fully understood (Colucci et al. 2014). A review by J. Zhang et al. shows that the uterine natural killer cells exert dual action during pregnancy protecting the fetus from the mother and vice versa (Zhang et al. 2015). Bridging male and female gametogenesis, A. Rodriguez and S. Pangas tell us how sumoylation, a prominent type of stable post-translational protein modification, regulates both spermatogenesis and oogenesis in humans and rodents (Rodriguez and Pangas 2015).

Infertility treatment cycle numbers are increasing both in developing and developed countries as a result of technological improvements and increased awareness of therapeutic options. While traditionally limited to subjective semen analysis and relegated to the back of infertile couple evaluation, male infertility diagnostics now benefit from new omics technologies and systems approaches (Baker et al. 2010; Mao et al. 2014), as reviewed from the point of view of sperm proteome's post-translational modifications by M. Baker (2015). Particularly exciting in this line of inquiry is the prospect that, in addition to paternal genes, the fertilizing human spermatozoon could deliver regulatory proteins and small RNAs to the oocyte at fertilization (Sendler et al. 2013), thus influencing the course of early embryo development and possibly promoting non-Mendelian transgenerational inheritance, considered in a review by Jodar et al. (2015). Rapid growth of sperm databases generated by the boom in sperm 'omics' makes it difficult to extract clinically-relevant information from the bulk of proteomic, genomic and epigenomic data. Finding a method in the mayhem, D. Carell et al. dissect clinically-relevant bioinformatics-based approaches to human male infertility (Carrell et al. 2015). Human and mammalian animal spermatozoa acquire their fertilizing potential during epididymal passage, a crucial step in gametogenesis that assures normal sperm function and may even serve as a site of post-testicular sperm quality control, as suggested by the newest findings of N. Da Silva and C. Barton. Having a previously unrecognized role in epididymal function and sustenance, the recently discovered network of dendritic cells and macrophages (Da Silva et al. 2011) has the ability to modulate immunoprotective function of male excurrent duct system, and even to phagocytose the dead epithelial cells and spermatozoa (Da Silva and Barton 2015). Such knowledge has implications for both ART and contraceptive development. Not to be forgotten in this utilitarian translational view of reproductive research is the contribution of reproductive biologists to our understanding of evolution, as exemplified in the review of the evolution of sex chromosome and autosomal genes responsible for reproductive function by Mordhorst et al. (2015).

\section{Conclusions and perspectives}

While not all-encompassing, the present Special Issue on Reproduction offers meaningfully reviewed and organized basic research data and novel ideas that will inform the efforts towards improving reproductive efficiency in food animals, developing better biomedical models, optimizing assisted reproductive therapies and formulating novel approaches to family planning and population control policy. In particular, non-hormonal male and female contraceptive approaches are desirable, combining contraceptive and anti-STD action. Near future challenges include the integration of cell biological/ molecular approaches with bioinformatics, omics and reproductive systems biology, and the translation of research findings from laboratory to farm, table and clinic.

\section{References}

Baker MA (2015) Proteomics of post-translational modifications of mammalian spermatozoa. Cell Tissue Res. doi:10.1007/s00441-0152249-x

Baker MA, Smith ND, Hetherington L, Taubman K, Graham ME, Robinson PJ, Aitken RJ (2010) Label-free quantitation of phosphopeptide changes during rat sperm capacitation. J Proteome Res 9: 718-729 
Bianchi E, Doe B, Goulding D, Wright GJ (2014) Juno is the egg Izumo receptor and is essential for mammalian fertilization. Nature 508: 483-487

Bott RC, Clopton DT, Fuller AM, McFee RM, Lu N, Cupp AS (2010) KDR-LacZ-expressing cells are involved in ovarian and testisspecific vascular development, suggesting a role for VEGFA in the regulation of this vasculature. Cell Tissue Res 342:117-130

Carrell DT, Aston KI, Oliva R, Emery BR, De Jonge CJ (2015) The "Omics" of human male infertility: integrating big data in a A systems biology approach. Cell Tissue Res. doi:10.1007/s00441-0152320-7

Chavez SL, Loewke KE, Han J, Moussavi F, Colls P, Munne S, Behr B, Reijo Pera RA (2012) Dynamic blastomere behaviour reflects human embryo ploidy by the four-cell stage. Nat Commun 3:1251

Chowdhury I, Xu W, Stiles JK, Zeleznik A, Yao X, Matthews R, Thomas K, Thompson WE (2007) Apoptosis of rat granulosa cells after staurosporine and serum withdrawal is suppressed by adenovirus-directed overexpression of prohibitin. Endocrinology 148:206-217

Chowdhury I, Thomas K, Thompson WE (2015) Prohibitin (PHB) roles in granulosa cell physiology. Cell Tissue Res. doi:10.1007/s00441015-2302-9

Colucci F, Moffett A, Trowsdale J (2014) Medawar and the immunological paradox of pregnancy: 60 years on. Eur J Immunol 44:18831885

Da Silva N, Barton CR (2015) Macrophages and dendritic cells in the post-testicular environment. Cell Tissue Res. doi:10.1007/s00441015-2270-0

Da Silva N, Cortez-Retamozo V, Reinecker HC, Wildgruber M, Hill E, Brown D, Swirski FK, Pittet MJ, Breton S (2011) A dense network of dendritic cells populates the murine epididymis. Reproduction 141:653-663

Daughtry B, Chavez S (2015) Chromosomal instability in mammalian pre-implantation embryos: potential causes, detection methods, and clinical consequences. Cell Tissue Res. doi:10.1007/s00441-0152305-6

Flechon J-E (2015) The acrosome of eutherian mammals. Cell Tissue Res. doi:10.1007/s00441-015-2238-0

Friend DR, Doncel GF (2010) Combining prevention of HIV-1, other sexually transmitted infections and unintended pregnancies: development of dual-protection technologies. Antivir Res 88(Suppl 1): S47-S54

Hansen PJ, Soto P, Natzke RP (2004) Mastitis and fertility in cattlepossible involvement of inflammation or immune activation in embryonic mortality. Am J Reprod Immunol 51:294-301

Hansen PJ, Dobbs KB, Denicol AC, Siqueira LGB (2015) Sex and the preimplantation embryo: implications of sexual dimorphism in the preimplantation period for maternal programming of embryonic developmen. Cell Tissue Res. doi:10.1007/s00441-015-2287-4

Hao L, Vassena R, Wu G, Han Z, Cheng Y, Latham KE, Sapienza C (2009) The unfolded protein response contributes to preimplantation mouse embryo death in the DDK syndrome. Biol Reprod 80:944953

Hassold T, Hunt P (2009) Maternal age and chromosomally abnormal pregnancies: what we know and what we wish we knew. Curr Opin Pediatr 21:703-708

Ignotz GG, Lo MC, Perez CL, Gwathmey TM, Suarez SS (2001) Characterization of a fucose-binding protein from bull sperm and seminal plasma that may be responsible for formation of the oviductal sperm reservoir. Biol Reprod 64:1806-1811

Jensen JT (2011) Why family planning matters. Rev Endocr Metab Disord 12:55-62

Jin M, Fujiwara E, Kakiuchi Y, Okabe M, Satouh Y, Baba SA, Chiba K, Hirohashi N (2011) Most fertilizing mouse spermatozoa begin their acrosome reaction before contact with the zona pellucida during in vitro fertilization. Proc Natl Acad Sci U S A 108:4892-4896

Jodar M, Sendler E, Krawetz S (2015) The protein and transcript profiles of human semen. Cell Tissue Res. doi:10.1007/s00441-015-2237-1

Latham KE (2015) Stress signaling in mammalian oocytes and embryos: a basis for intervention and improvement of outcomes. Cell Tissue Res. doi:10.1007/s00441-015-2124-9

Liu XJ (2015) Targeting oocyte maturation to improve fertility in older women. Cell Tissue Res. doi:10.1007/s00441-015-2264-y

Loureiro B, Bonilla L, Block J, Fear JM, Bonilla AQ, Hansen PJ (2009) Colony-stimulating factor 2 (CSF-2) improves development and posttransfer survival of bovine embryos produced in vitro. Endocrinology 150:5046-5054

Maalouf SW, Liu W-S, Pate JL (2015) MicroRNA in ovarian function. Cell Tissue Res. doi:10.1007/s00441-015-2307-4

Machaty Z (2015) Signal transduction in mammalian oocytes during fertilization. Cell Tissue Res. doi:10.1007/s00441-015-2291-8

Manjunath P, Lefebvre J, Jois PS, Fan J, Wright MW (2009) New nomenclature for mammalian BSP genes. Biol Reprod 80: 394-397

Mao S, Sendler E, Goodrich RJ, Hauser R, Krawetz SA (2014) A comparison of sperm RNA-seq methods. Syst Biol Reprod Med 60:308315

McGinnis LK, Luense LJ, Christenson LK (2015) MicroRNA in ovarian biology and disease. Cold Spring Harb Perspect Med 5(9):a022962. doi:10.1101/cshperspect.a022962

Mordhorst BR, Wilson ML, Conant GC (2015) Some assembly required: evolutionary and systems perspectives on the mammalian reproductive system. Cell Tissue Res. doi:10.1007/s00441-015-2257-x

Ortega MA, Marh J, Alarcon VB, Ward WS (2012) Unique pattern of ORC2 and MCM7 localization during DNA replication licensing in the mouse zygote. Biol Reprod 87:62

Ortega MA, Nguyen H, Ward WS (2015) ORC proteins in the mammalian zygote. Cell Tissue Res. doi:10.1007/s00441-015-2296-3

Plante G, Prud'homme B, Fan J, Lafleur M, Manjunath P (2015) Evolution and function of mammalian binder of sperm proteins. Cell Tissue Res. doi:10.1007/s00441-015-2289-2

Rodriguez A, Pangas SA (2015) Regulation of germ cell function by SUMOylation. Cell Tissue Res. doi:10.1007/s00441-015-2286-5

Sargent KM, Clopton DT, Lu N, Pohlmeier W, Cupp AS (2015) VEGFA splicing: divergent isoforms regulate spermatogonial stem cell maintenance. Cell Tissue Res. doi:10.1007/s00441-015-2297-2

Sendler E, Johnson GD, Mao S, Goodrich RJ, Diamond MP, Hauser R, Krawetz SA (2013) Stability, delivery and functions of human sperm RNAs at fertilization. Nucleic Acids Res 41:4104-4117

Suarez S (2015) Mammalian sperm interactions with the female reproductive tract. Cell Tissue Res. doi:10.1007/s00441-015-2244-2

Susor A, Jansova D, Anger M, Kubelka M (2015) Translation in the mammalian oocyte in space and time. Cell Tissue Res. doi:10. 1007/s00441-015-2269-6

Tsai PS, Garcia-Gil N, van Haeften T, Gadella BM (2010) How pig sperm prepares to fertilize: stable acrosome docking to the plasma membrane. PLoS One 5, e11204

van Gestel RA, Brouwers JF, Ultee A, Helms JB, Gadella BM (2015) Ultrastructure and lipid composition of detergentresistant membranes derived from mammalian sperm and two types of epithelial cells. Cell Tissue Res. doi:10.1007/ s00441-015-2272-y

Wang C, Zhang L, Jaeger LA, Machaty Z (2015) Store-operated Ca2+ entry sustains the fertilization $\mathrm{Ca} 2+$ signal in pig eggs. Biol Reprod 93(1):25. doi:10.1095/biolreprod.114.126151

Wells K (2015) Genetic engineering of mammals. Cell Tissue Res. doi: 10.1007/s00441-015-2321-6

Whitworth KM, Lee K, Benne JA, Beaton BP, Spate LD, Murphy SL, Samuel MS, Mao J, O’Gorman C, Walters EM, Murphy 
CN, Driver J, Mileham A, McLaren D, Wells KD, Prather RS (2014) Use of the CRISPR/Cas9 system to produce genetically engineered pigs from in vitro-derived oocytes and embryos. Biol Reprod 91:78

Wright GJ, Bianchi E (2015) The challenges involved in elucidating the molecular basis of sperm-egg recognition in mammals and approaches to overcome them. Cell Tissue Res. doi:10.1007/s00441-015-2243-3
Wu G, Fanzo J, Miller DD, Pingali P, Post M, Steiner JL, ThalackerMercer AE (2014) Production and supply of high-quality food protein for human consumption: sustainability, challenges, and innovations. Ann N Y Acad Sci 1321:1-19

Zhang J, Dunk C, Croy BA, Lye SJ (2015) To serve and to protect: the role of decidual innate immune cells on human pregnancy. Cell Tissue Res. doi:10.1007/s00441-015-2315-4 